IZA DP No. 7130

10 Years After:

EU Enlargement, Closed Borders, and Migration to Germany

Benjamin Elsner

Klaus F. Zimmermann

January 2013 


\title{
10 Years After: EU Enlargement, Closed Borders, and Migration to Germany
}

\author{
Benjamin Elsner \\ IZA and IIIS \\ Klaus F. Zimmermann \\ IZA and Bonn University \\ Discussion Paper No. 7130 \\ January 2013
}

IZA

P.O. Box 7240

53072 Bonn

Germany

Phone: +49-228-3894-0

Fax: +49-228-3894-180

E-mail: iza@iza.org

\begin{abstract}
Any opinions expressed here are those of the author(s) and not those of IZA. Research published in this series may include views on policy, but the institute itself takes no institutional policy positions. The IZA research network is committed to the IZA Guiding Principles of Research Integrity.

The Institute for the Study of Labor (IZA) in Bonn is a local and virtual international research center and a place of communication between science, politics and business. IZA is an independent nonprofit organization supported by Deutsche Post Foundation. The center is associated with the University of Bonn and offers a stimulating research environment through its international network, workshops and conferences, data service, project support, research visits and doctoral program. IZA engages in (i) original and internationally competitive research in all fields of labor economics, (ii) development of policy concepts, and (iii) dissemination of research results and concepts to the interested public.
\end{abstract}

IZA Discussion Papers often represent preliminary work and are circulated to encourage discussion. Citation of such a paper should account for its provisional character. A revised version may be available directly from the author. 


\section{ABSTRACT \\ 10 Years After: \\ EU Enlargement, Closed Borders, and Migration to Germany}

We study how the EU enlargement in 2004 and the Great Recession in the late 2000s have shaped the scale and composition of migration flows from the New Member States to Germany. We demonstrate that immigration increased substantially despite the restrictions on the German labor market, and that net flows decreased to zero at the outset of the recession. The cohorts arriving after 2004 had on average a lower education than the previous arrival cohort, but the wage gap compared to Germans became narrower over time. Almost 10 years after EU enlargement, we re-assess the transitional arrangements, and argue that Germany would have been better off, had it immediately opened its labor market. Finally, the Great recession allows us to study how effective migration within the EU is as an adjustment mechanism. Our data clearly show an increase in immigration from countries that were hit by the crisis, although the annual net flows are still too small to significantly reduce unemployment in the countries hit by the crisis.

JEL Classification: F22

Keywords: $\quad$ EU enlargement, migration, Germany

Corresponding author:

Benjamin Elsner

IZA

P.O. Box 7240

53072 Bonn

Germany

E-mail: elsner@iza.org 


\section{Introduction}

Almost a decade has passed since the Eastern enlargement of the European Union (EU) in 2004. Germany has been a special case among the old member states of the EU for at least two reasons. First, the country restricted access to its labor markets for workers from the New Member States (NMS) until 2011; and second, the German labor market weathered the Great Recession without an increase in unemployment.' In this chapter we analyze how both events --- EU enlargement and the economic crisis --- shaped migration flows to Germany.

As we will argue, both events changed the attractiveness of Germany as a destination for immigrants. The labor market restrictions after 2004 made Germany less attractive for migrants compared to countries that opened their labor markets immediately, while we expect the stable labor market during the economic crisis to be a pull factor for migrants from the NMS.

This chapter extends previous work by Brenke, Yuksel and Zimmermann (2009) in two important dimensions. First, by using more complete data, we are able to give a broader perspective on EU enlargement and migration to Germany. The aggregate data allow us to document a significant surge in immigration from the NMS to Germany after 2009. Moreover, a comparison with immigration from the old member states suggests that the surge in immigration was mainly driven by the recession and to a lesser extent by the end of the transitional arrangements. Second, we are able to compare the characteristics and the economic success of three cohorts of immigrants from the NMS: those who came before EU enlargement, those who came right after, and those who came during the recession. Also, we can track earlier arrival cohorts over time and analyze their assimilation patterns. 
We begin by analyzing aggregate migration flows to and from Germany. EU enlargement mostly changed inflows. Despite the restrictions on the German labor market, immigration from the EU8 and EU2 countries increased significantly after the enlargement rounds in 2004 and 2007." The Great Recession, by contrast, had no impact on inflows but a strong impact on outflows, especially for Polish migrants. While in 2006 inflows from Poland exceeded outflows by 50,000, outflows were as large as inflows in 2008. Both events also shaped the demographic composition of migration flows. Using German census data from 2000 to 2009, we demonstrate that migrants from the NMS that came right after EU enlargement had less education, while those that came after 2008 had slightly more education compared to the cohort that arrived before 2004. Given that labor market restrictions did not apply to self-employed workers, it is not surprising that the share of selfemployed among immigrants that came after 2004 was more than 5 times higher than before EU enlargement. Compared to Germans of similar age, immigrants from the NMS had more education, but earned considerably less. Using regression analysis, we show that immigrants that came after 2004 had on average one more year of education, but they earned between $25 \%$ and $40 \%$ less than natives with the same education and age. The earnings gap between immigrants and natives was smaller for more recent cohorts.

Based on our findings, we critically assess the decision of the German government to restrict access to its labor market. Although the absence of a suitable counterfactual makes an exact evaluation difficult, the evidence suggests that Germany would have been better off without the restrictions. The recession also allows us to analyze to what extent migration can help to absorb asymmetric macroeconomic shocks. We show that immigration from crisis-hit countries, especially from Southern Europe, has increased substantially during the crisis, but its level is too low to significantly reduce unemployment in Southern Europe. 


\section{Between EU enlargement and the "labor market miracle":}

\section{immigration to Germany in the 2000s}

Before we turn to the analysis of migration flows throughout the 2000 s, it is useful to look at two important institutional and economic developments that affected the German labor market and shaped migration flows to and from Germany.

The first important institutional development was the introduction of transitional arrangements after the enlargement round in 2004 , according to which the old member states were allowed to restrict access to their labor markets for workers from the NMS until 2011. The German government opted for these labor market restrictions and kept them in place until 2011.iii The restrictions made Germany a less attractive destination compared to countries that opened their labor markets immediately. While free movement of workers is a core principle of the European Union, the German government was concerned that an expected large inflow of low-skilled workers from the NMS would increase unemployment, and impose a burden on the welfare state. The restrictions applied in principle to all workers, but excluded students, self-employed workers, and seasonal workers on a short-term contract. Not surprisingly, the introduction of the transitional arrangements led to a diversion of migration flows away from Germany and towards the UK and Ireland, who had not opted for the constraints. While in 2000 , around $80 \%$ of all EU8 migrants in the EU lived in Germany and Austria, after 2004 the majority lived in the UK and Ireland (Boeri \& Brücker, 2001; Baas \& Brücker, 2012).

[Figure 1 about here] 
A second important development was the worldwide economic crisis, which hit the German economy after 2008, but which left the German labor market largely unaffected. As Figure 1 shows, GDP per capita dropped by about 5\% from 2008 to 2009 and recovered thereafter, while the unemployment rate remained stable. The favorable labor market conditions during the crisis (Rinne and Zimmermann, 2012) made Germany a more attractive destination relative to other European countries that were hit harder by the financial crisis. In particular, the labor market position of migrants had improved with the reform policies early in the 2000 s.

With these observations in mind, we now turn to the aggregate inflows to Germany in Figure 2. The flow data is taken from the Central Registry of Foreigners (Ausländerzentralregister) and covers all foreign nationals that register or de-register in Germany in a given year. Both immigration and emigration flows reflect lower bounds, as the inflows may not capture seasonal workers that come to Germany for a short spell, while outflows may be under-stated because people did not deregister, although they are legally obliged to.

\section{[Figure 2 about here]}

The largest share of immigrants came from Poland, although inflows from Romania and Bulgaria have increased considerably since 2007, while inflows from other EU8 countries remained constant. Figure 2 shows that the labor market restrictions did not prevent immigration from the NMS to Germany. The inflows from Poland, Romania, and Bulgaria, show a clear structural break in 2004 and 2007. Inflows from these countries have been more or less constant until the enlargement rounds, and increased sharply after EU enlargement.

From the inflows it is less clear how the economic crisis has affected migration to Germany. On the one hand, the number of Polish immigrants dropped, but the number of Romanians and Bulgarians increased at the same time. Unlike Poles, they were not allowed to move freely to the UK 
after enlargement. A more conclusive picture emerges from the net flows in the graph on the right in Figure 2. The crisis had only a small impact on inflows, but outflows from all countries increased. The increase in outflows was particularly drastic for Polish immigrants: net flows from Poland decreased from over 50,000 in 2006 to zero in 2008 and 2009. After 2009, they surged in a similar fashion, which can be explained by the favorable conditions on the German labor market, and by the expiration of the transitional arrangements in 2011. It remains to be seen, however, whether this increase was a once-off event, or whether migration remains at this level.

To disentangle the increase in migration due to the opening of the German labor market from the increase due to the crisis, it is helpful to compare net flows from the NMS with net flows from other EU countries that were hit hard by the crisis, mainly in Southern Europe. Workers from these countries were allowed to move to Germany throughout the 2000 s, so that an increase in inflows from these countries can mainly be attributed to the crisis. In Figure 2 we plot the migration flows of the five countries that were hit hardest by the economic crisis. These countries are often referred to as PIIGS. ${ }^{\text {iv }}$ Immigration from PIIGS has been decreasing in the first half of the 2000s, and has been steadily increasing since. The net flows, in contrast, were negative until 2009 and show a sharp increase in2010 and 2011. The increase in migration from countries that were hit by the crisis provide evidence that the stable German labor market is indeed a pull factor for migrants. 


\section{Who migrated to Germany?}

\section{III.I. Descriptive evidence}

After having looked at the aggregate picture of immigration to Germany, we now turn to the demographics of immigrants from the NMS. As the register data only give aggregate flows by gender, we rely in this section on stock data from the German microcensus. The microcensus is a $1 \%$-random sample of the German population, collected annually by the German Statistical Office. It is a rotating survey without panel structure, in which households are interviewed in four consecutive years. Individuals are legally obliged to take part in the survey, which ensures a high response rate. For our analysis we use the scientific use files provided by the German Statistical Office.

In this section we want to investigate how the labor market restrictions and the financial crisis changed the characteristics of EU8 immigrants, and how both events affected their labor market outcomes. We compare three arrival cohorts:

1. immigrants who arrived before EU enlargement, between 2001 and 2003,

2. those who arrived after 2004, between 2005 and 2007, and

3. immigrants who arrived during the economic crisis, in 2008 and 2009.

Data on these cohorts are taken from the microcensus in 2004, 2008, and 2009, respectively. To make the three cohorts comparable over time, we restrict the data to EU8-migrants. We define as a migrant a citizen from the NMS who migrated to Germany in the respective period. As is common with German data, the migrant definition has to rely on citizenship rather than place of birth. We begin by comparing the descriptive statistics of Germans and immigrants from the three arrival cohorts. In a second step, we systematically compare Germans and EU8-immigrants using regression analysis. 
Table 1 displays the basic demographic characteristics of different arrival cohorts between 18 and 64 years. Throughout the 2000s, new immigrants were on average younger than Germans. Men were under-represented among migrants: around $60 \%$ of immigrants were women. ${ }^{v}$ Migrants were also more educated than Germans; they had a higher share among workers with upper secondary or third-level education, and a lower share of workers with a lower secondary education. Over time, the average education of new immigrants changed; after EU enlargement the education level decreased, while it increased again during the crisis, when relatively more migrants with a third-level degree came.

\section{[Table 1 about here]}

EU enlargement clearly changed the employment patterns of migrants. Given that selfemployed workers could freely move to Germany from 2004, it is no surprise that self-employment among immigrants increased dramatically after 2004. The sectoral distribution of migrants, shown in Figure 3, shifted as well. Before 2004, migrants were vastly over-represented among non-working people, which includes students and other people who are not part of the workforce. The relative share of migrants that are not working has decreased to $3 \%$ until 2009. All through the 2000 s, migrants have been under-represented in the service sector, and the gap has become even larger over time, while new migrants have been working more in blue collar industry jobs. For white-collar industry jobs, the share of migrants and Germans has been constant over time.

\section{[Figure 3 about here]}


Migrants had lower monthly earnings than Germans, but the earnings gap narrowed over time. The 2001-2003 cohort earned around $60 \%$ of the average German wage, while the $2008-2009$ cohort earned $75 \%$. One explanation for the earnings gap between immigrants and Germans is the difference in work experience; migrants may earn less than Germans, as they are on average younger. Another explanation is sector and industry affiliation. Immigrants may cluster in low-paid jobs, especially if they do not have location-specific skills or access to networks that provide information on better job opportunities.

In sum, migrants from the NMS have a higher education than Germans, but they are more likely to be self-employed, more concentrated in blue-collar jobs, and earn less than the average German worker. At least two explanations can be given for the discrepancy between earnings and education. One factor is down-skilling. Immigrants may initially accept a job for which they are overqualified and move on to better-paid jobs at a later stage (Chiswick \& Miller, 2010; Kahanec \& Zimmermann, 2009; Piracha \& Vadean, 2013). Another explanation is the imperfect comparability of educational degrees. Given education is self-reported, migrants may misreport their education. And even if they correctly state their education, a university degree from their home country may not have the same value with German employers than a German degree.

\section{III.II. Regression analysis: a closer look}

It is difficult to assess the magnitude of down-skilling based on descriptive statistics, because migrants and natives differ in observable and unobservable skills. In this section we compare EU8immigrants and Germans with the same observable characteristics, such as age, education, and gender, and sector. We do so by running an OLS regression of the variable of interest --- education or wages --- on a set of arrival cohort dummies and several control variables that capture systematic differences in wages with respect to age and gender. Germans are the base category, so that the 
coefficients can be interpreted as the difference between immigrants and Germans of the same age and gender. By introducing additional controls, such as sector fixed effects, we can make a comparison of migrants and Germans with similar characteristics within the same sector, and see whether the education and wage gaps can be explained by the sorting of migrants into low-paid jobs. As we have multiple census rounds, we can track earlier arrival cohorts over time, and see how their outcomes have changed with duration of stay.

\section{[Table 2 about here]}

We first compare the years of education of EU8 migrants and Germans in Panel A of Table 2. As Columns 1-3 show, migrants that arrived before 2004 had a similar education compared to Germans, while those arriving after 2004 had one more year of schooling. In Columns 4-6 we compare the education of migrants and Germans within the same sector. For migrants who arrived before 2004 the difference in education is statistically significant, albeit very small, with 0.4 more years of education in 2004, and 0.26 in 2009. For the cohorts arriving after 2004 the difference in education is significant, with one more year of schooling than Germans. This difference is the same within and between sectors. When we assume that the education distribution of Germans did not change over time, then the results in Panel A indicate that migrants that came after 2004 had more years of education than those that came before --- the opposite of the finding based on the descriptive statistics. One explanation for the different results is sorting of immigrants into jobs for which they are over-qualified. If migrants that came after 2004 worked in sectors with a lower average education, then the average degree of over-qualification is larger. This finding is consistent with the shift in the sectoral distribution towards blue-collar jobs.

Next we analyze the wage gap between immigrants and natives in Panel B of Table 2. Columns 1-3 compare migrants and natives with the same education, age, and gender. The coefficients can be interpreted as a percentage difference. 0.410 means that migrants of this cohort 
earn on average $41 \%$ less than natives. Clearly, all arrival cohorts earned less than comparable Germans, but the earnings gap was more than twice as large for the pre-2004 cohort compared to later cohorts. Within the $2001 / 2003$ and the $2005 / 2007$ cohorts the wage gap narrowed over time from $41 \%$ to $24 \%$, and from $19 \%$ to $14 \%$, respectively. The narrowing of the earnings gap can be due to wage assimilation, for example if migrants move to better-paid jobs. It can also be explained by selective out-migration, which occurs if low paid workers are more likely to return to their home country than high-paid workers. Given the absence of disaggregate data on out-migration from Germany, however, we are not able to disentangle these two effects. In Columns 4-6 of Panel B we compare migrants and Germans with the same education within the same sector. ${ }^{\text {vi }}$ The coefficients are smaller in magnitude than in Columns 1-3, which indicates that migrants tend to sort into lowpaid jobs. Once they are compared to Germans in the same sector and with the same education, the earnings gap becomes smaller.

In sum, migration flows from the NMS to Germany have changed in scale as well as in demographics. The two cohorts arriving after EU enlargement were significantly different from the cohort that moved to Germany right before the enlargement. While all cohorts had a higher average education than Germans, post-enlargement immigrants had less education than immigrants that arrived before 2004. Yet, post-enlargement immigrants earned more on average. ${ }^{\text {vii }}$

A potential concern is that the difference between the cohorts may be due to sample selection. Although the micro-census is representative for the entire population living in Germany at the time of the survey, it possibly under-counts temporary workers who only stay in Germany for a few weeks. If temporary workers --- for example those working in agriculture or construction --- are less skilled than non-temporary workers, then we are possibly over-estimating the earnings and education of later cohorts. By introducing sector fixed effects, we can reduce this bias. The similar results with and without sector fixed effects indicate that the possible selection bias is negligible. 


\section{What can we learn from the German case?}

\section{IV.I. Was Germany right to restrict its labor markets?}

Before EU enlargement, Germany decided to restrict its labor market for workers from the NMS in accordance with the transitional arrangements, and only lifted the restrictions once it was legally obliged to in 2011. In light of the results from the previous section, the question arises whether, in hindsight, these restrictions were beneficial for Germany.

An answer to this question is difficult, because we do not know the counterfactual. Simply put, we do not know how many and what type of migrants would have come to Germany, had the country opened its borders in 2004 . Moreover, we do not have a historical precedent of a large migration wave that could serve as a benchmark for migration after 2004. Although 2004 and 2007 were not the first enlargement rounds, they were historically unique due to the large income differences between the old and new member states, which were much larger than in the case of Spain and Portugal in the 1980s. Given these income differences, it was not surprising that EU enlargement triggered an unprecedented migration wave, with around $6 \%$ of the Polish, Latvian, and Slovak, and 9\% of the Lithuanian workforce emigrating after 2004 (Elsner, 2011, 2013).

While we cannot exactly say how many migrants would have come to Germany in absence of the restrictions, the data indicate that the restrictions led to migration diversion. Instead of moving to Germany, migrants from the NMS mainly went to the UK and Ireland, which had a booming economy at the time, and which opened their labor markets in 2004. Given that Germany is geographically close to the NMS, and given that the majority of immigrants from the NMS were living in Germany before EU enlargement, it is plausible that immigration would have been higher without the restrictions. 
Besides the scale of immigration, the transitional arrangements may have also influenced the skill composition of migrants. When we compare the characteristics of EU8 migrants to Germany with those of migrants to the UK, we can see two important differences: migrants to the UK were on average 6 years younger and their share of workers with a third-level degree was 12 percentage points higher. ${ }^{\text {viii }}$ Despite these differences, it is not clear how many younger and better-educated immigrants would have gone to Germany instead of the UK.

Suppose for a moment that, without the restrictions, more, younger, and better educated migrants would have come to Germany; what would have been the consequences for German labor market? Economic theory has a very clear answer as to whether migration restrictions are beneficial: they lead to welfare losses for the receiving country and therefore should be abandoned. In other words, theory suggests that Germany would have been better off with open borders, receiving more migrants. But while the average person gains from immigration, there may be winners and losers. An inflow of better-educated workers may increase competition among high-skilled workers. Depending on the rigidity of the labor market, this situation either leads to lower wages or lower employment for high-skilled natives, and has the opposite effect for low-skilled workers. ${ }^{i x}$

The extent to which immigration affects wages and employment depends on the degree of substitutability between migrants and natives. The more substitutable migrants and natives are, the stronger is the effect. Recent studies by D'Amuri et al. (2010) and Brücker \& Jahn (2011) have shown that Germans and immigrants with the same education and work experience are indeed imperfect substitutes. Hence, immigration should only have a moderate effect on wages and employment of natives. Based on this line of argumentation, and in view of the many young and well-educated migrants that went to the UK and not to Germany, we conclude that Germany missed a chance by not opening up its borders in 2004. The fear of the German government that thousands of low-skilled workers would emigrate from the NMS turned out not to be true. Instead, EU8 migrants were 
actually better-educated than the average native. As shown in previous work by Brenke et al. (2009), immigrants from the EU8 countries mostly competed with previous immigrants and not with natives. For Germany as a whole, the costs of the restrictions exceeded the benefits by far.

\section{IV.II. Is migration a suitable adjustment mechanism?}

In the previous section we looked at Germany in isolation and evaluated whether migration restrictions were beneficial for the country. When we shift our focus to the entire EU, free migration certainly brings economic benefits. First, it leads to efficiency gains, as workers can move to places where they are most productive. Second, migration can serve as an adjustment mechanism that helps absorbing asymmetric shocks.

A good example for an asymmetric shock is the recent financial crisis, which hit Southern Europe more than Germany. Take the example of Spain, which experienced a deep recession and a sharp increase in unemployment. Given that Spain is part of a monetary union, it cannot devalue its currency, so that it has to devalue internally by cutting wages and prices. If wages are rigid, then internal devaluation results in higher unemployment. Migration from Spain to Germany could reduce the burden that comes with internal devaluation and would take pressure off Spanish wages. Even if two countries are not part of a monetary union --- for example Germany and Poland --- migration can help absorbing asymmetric shocks.

Based on the German experience, can we conclude that migration is an effective adjustment mechanism? To answer this question, we return to the aggregate migration flows in Figure 2. Clearly, net flows to Germany from all countries have been increasing since 2009. With respect to migration from the EU8, this increase is not surprising given that labor market restrictions were lifted in 2011, and that the main destination after 2004 --- the UK and Ireland --- suffered a deeper recession than 
Germany. During the crisis, net flows from Southern Europe also increased sharply, and workers from these countries have been allowed to move to Germany throughout the 2000s.

The aggregate flows to Germany give evidence that migration does respond to asymmetric shocks. Workers from crisis-hit countries move to countries with more favorable economic conditions. So far, the increase in migration during the recession is far from being large, but it can further increase if unemployment in Southern Europe remains high. The annual net migration of 40,000 workers from Southern Europe in 2011, however, is too small to substantially reduce the pressure on the labor markets in the source countries.

Migration rates can be low for multiple reasons: language and cultural differences, the difference in the formal requirements for certain occupations (e.g. lawyers), and preferences to stay in their home country despite unfavorable economic conditions. Governments only have limited options to increase migration flows within the EU in the short run. With the end of the transitional arrangements in 2011, workers are allowed to move to another country. But what makes them actually move remains an open question. 


\section{Concluding remarks}

In this chapter we have shown how institutional arrangements and macroeconomic fundamentals shaped immigration from the NMS to Germany throughout the 2000s. While Germany was the main destination for migrants from the NMS before the EU enlargement in 2004, it became a less attractive destination when the German government opted for temporary labor market restrictions for immigrants from the NMS. Yet the country became more attractive for immigrants in the late 2000s, when the German labor market weathered the recession without an increase in unemployment.

In contrast to previous studies that only use data until the mid-2000s, we are able to provide a broader picture of the scale and composition of migration flows from the NMS to Germany after the EU enlargement. The longer time horizon also allows us to compare the economic performance of different arrival cohorts, and to analyze the assimilation pattern of the earlier cohorts.

Three main findings emerge from our analysis. First, both the transitional arrangements and the economic crisis shaped immigrant inflows and outflows. Inflows from the NMS initially increased after 2004 despite the labor market restrictions. They decreased until 2007 and surged again with the onset of the recession. Outflows from Germany responded exactly the opposite way. They balanced with inflows in 2006 and 2007, and dropped sharply during the recession.

Second, evidence suggests that the recent surge in immigration from the NMS is mainly driven by the recession, and to a lesser extent by the expiration of the transitional arrangements. This can be seen from a comparison with inflows from Southern Europe, which show the same pattern as inflows from the NMS. As workers from Southern Europe were allowed to migrate to 
Germany throughout the 2000s, the surge in immigration from this region can be attributed to the crisis.

Third, immigrants from the NMS had a higher education than comparable natives, but they earned considerably less. These results hold when we compare both groups within the same sector and the same education group. Over time, the over-education of immigrants increased, while the immigrant-native wage gap became more narrow.

Based on our findings, we conclude that Germany would have been better off had it opened its labor markets in 2004. By opting for the transitional arrangements, the country missed out on an inflow of young and well-educated workers who went to the UK and Ireland instead.

The recent surge in immigration to Germany --- especially from countries that were hit hard by the recession --- show that migration can indeed work as an adjustment mechanism, and help to absorb asymmetric shocks.

Our findings open several directions for future research. One important topic is the potential role of migration in absorbing asymmetric shocks. As a first step, it would be important to establish the optimal level of bilateral migration flows if migration was the only adjustment mechanism. The optimal level of migration can then serve as a benchmark to which one could compare current migration flows. If more migration is desirable, it should be possible to design policies that increase migration flows within Europe and elsewhere.

Another important research topic related to this chapter is temporary and circular migration. The aggregate data show a strong response of outflows to macroeconomic fundamentals. While we are able to quantify how the recession shapes the scale and composition of migration flows, we would require more detailed data to look at the duration of stay of migrants. For the design of migration policy it would be important to quantify the extent of circular migration, to uncover the 
underlying selection patterns, and to identify the drivers of the decision to migrate, and the decision to leave. ${ }^{x}$ 


\section{References}

Baas, T. and H. Brücker (2012), 'The Macroeconomic Consequences of Migration Diversion: Evidence from Germany and the UK', Structural Change and Economic Dynamics, 23 (2), pp. 180-194.

Boeri, T. and H. Brücker(2001), 'Eastern Enlargement and EU-Labour Markets', World Economics, 2 (1), pp. 49-68.

Brenke, K., Yuksel, M and K.F. Zimmermann, (2009), 'EU Enlargement under Continued Mobility Restrictions: Consequences for the German Labor Market', in: M. Kahanec and K.F. Zimmermann (eds.), EU Labor Markets After Post-Enlargement Migration, Springer-Verlag, pp. 111-129.

Brücker, H. and E.J. Jahn, (2011), 'Migration and Wage Setting: Reassessing the Labor Market Effects of Migration', Scandinavian Journal of Economics, 113 (2), pp. 286-317.

Chiswick, B.R., and P.W. Miller, (2010), 'Educational Mismatch: Are High-Skilled Immigrants really Working in High-Skilled Jobs and the Price they Pay if they Don't.', in B.R. Chiswick (ed.), High-Skilled Immigration in a Global Labor Market, American Enterprise Institute Press,pp. 111-154.

Christen, T.G., (2004), ,Der Zugang zum Deutschen Arbeitsmarkt nach der EU-Erweiterung', Bundesarbeitsblatt, 3.

Constant, A., O. Nottmeyer and K.F. Zimmermann, 'The Economics of Circular Migration', in A. Constant and K.F. Zimmermann (eds.), International Handbook of the Economics of Migration, Cheltenham, UK, Edward Elgar Publishing, ch. 3. 
D'Amuri, F., G.I.P Ottaviano and G. Peri, (2010), 'The Labor Market Impact of Immigration in Western Germany in the 1990s', European Economic Review, 54, pp. 550-570.

Dustmann, C., T. Frattini and C. Halls, (2010), 'Assessing the Fiscal Costs and Benefits of A8 Migration to the UK', Fiscal Studies, 31 (1), pp. 1-41.

Elsner, B., (2011), 'Emigration and Wages: The EU Enlargement Experiment', IZA Discussion Paper, 6111.

Elsner, B., 2013, 'Does Emigration Benefit the Stayers? Evidence from EU Enlargement', Journal of Population Economics, 26 (2).

Kahanec, M. and K.F. Zimmermann (2009), 'International Migration, Ethnicity and Economic Inequality', in Oxford Handbook on Economic Inequality, Oxford, UK: Oxford University Press, pp. 455-490.

Piracha, M. and F. Vadean (2013), 'Migrant Educational Mismatch and the Labor Market', in A. Constant and K.F. Zimmermann (eds.), International Handbook of the Economics of Migration, Cheltenham, UK, Edward Elgar Publishing, ch. 9.

Rinne, U. and K. F. Zimmermann (2012), 'Another economic miracle? The German labor market and the Great Recession', IZA Journal of Labor Policy, 1:3. 


\section{Figures}

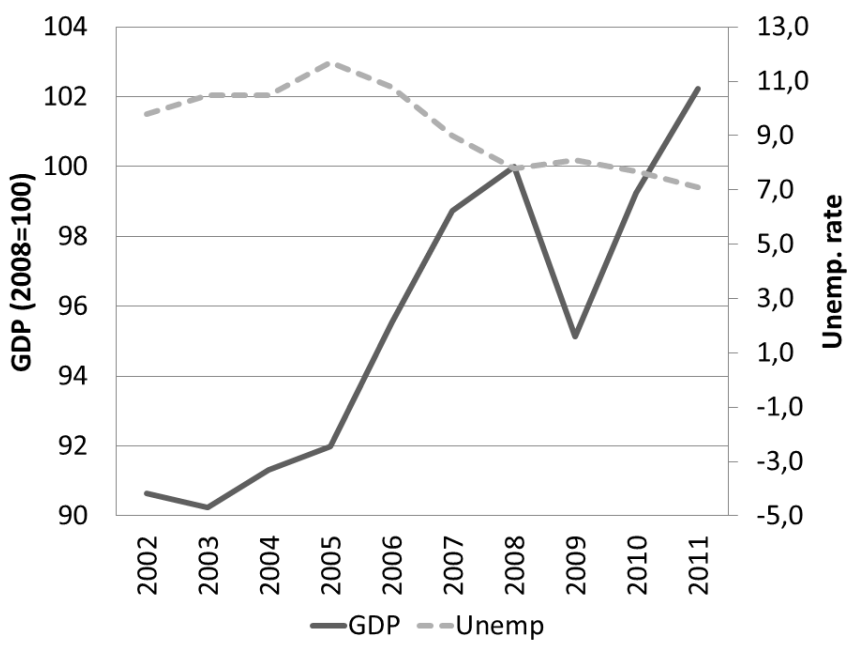

Figure 1 - GDP and unemployment in Germany

Notes: Unemployment rate (right scale) in \%. Real GDP (left scale), 2008=100.

Source: Destatis
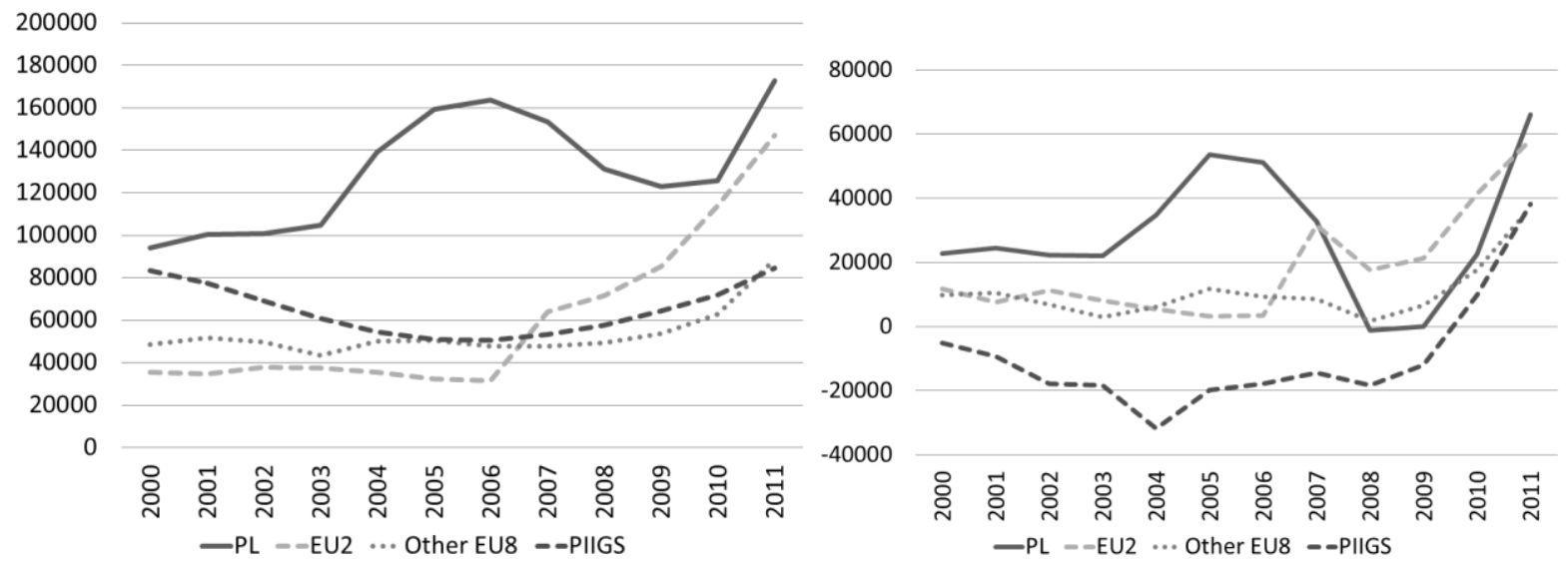

Figure 2 - Immigration to Germany (left), Net migration (right)

Notes: Left: migrant inflows to Germany per year. Right: net flows (inflows minus outflows) per year.

Source: Destatis, Ausländerzentralregister 

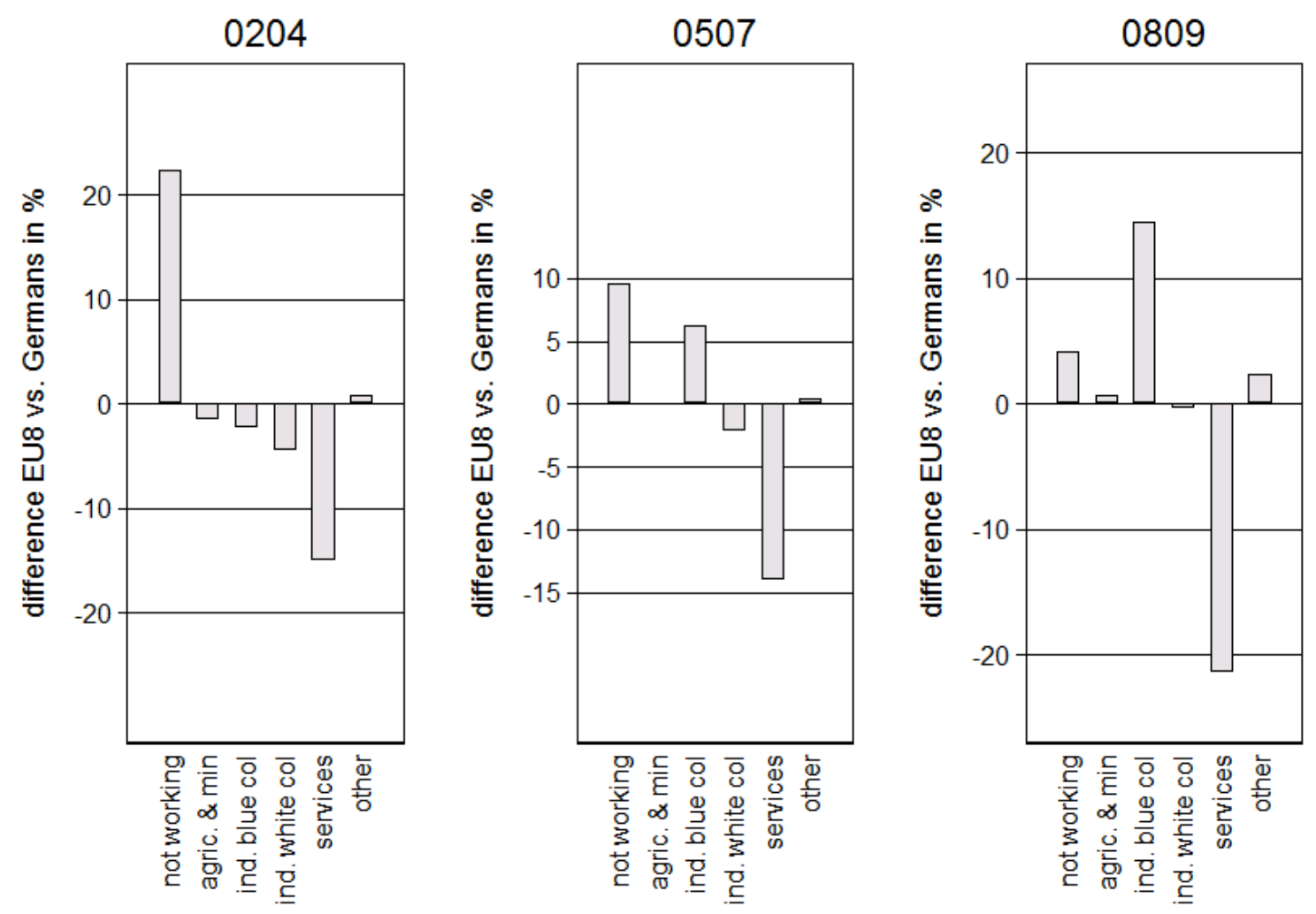

Figure 3 - Sectoral distribution of A8 immigrants (relative to Germans)

Notes: The graphs display the difference in the sectoral distribution between Germans and three arrival cohorts of $A 8$ migrants. For the arrival cohorts 2001/03, 2005/07, and 2008/09, we use the microcensuses of 2004, 2008, and 2009, respectively. 


\section{Tables}

Table 1 - Demographics of EU8 Immigrants in Germany

\begin{tabular}{|c|c|c|c|c|c|c|}
\hline & \multicolumn{2}{|c|}{$\begin{array}{l}\text { Arrival Cohort } \\
2001-2003\end{array}$} & \multicolumn{2}{|c|}{$\begin{array}{l}\text { Arrival Cohort } \\
2005-2007\end{array}$} & \multicolumn{2}{|c|}{$\begin{array}{l}\text { Arrival Cohort } \\
2008-2009\end{array}$} \\
\hline & Immig. & Ger. & Immig. & Ger. & Immig. & Ger. \\
\hline Age & 31 & 42 & 34 & 42 & 33 & 43 \\
\hline Male (\%) & 37 & 50 & 39 & 50 & 41 & 50 \\
\hline Married (\%) & 67 & 59 & 57 & 55 & 46 & 55 \\
\hline Dropouts (\%) & 7 & 7 & 4 & 2 & 3 & 3 \\
\hline Lower Sec. (\%) & 38 & 60 & 44 & 60 & 41 & 59 \\
\hline Upper Sec. (\%) & 32 & 17 & 29 & 20 & 27 & 20 \\
\hline Third-level (\%) & 23 & 16 & 23 & 18 & 29 & 18 \\
\hline Unemployed (\%) & 18 & 11 & 14 & 8 & 9 & 8 \\
\hline Avg. wage & 847 & 1,423 & 1,054 & 1,513 & 1,155 & 1,534 \\
\hline Permanent emp. (\%) & 54 & 79 & 37 & 78 & 35 & 78 \\
\hline Temporary emp. (\%) & 40 & 10 & 23 & 11 & 36 & 11 \\
\hline Self-employed (\%) & 6 & 11 & 41 & 11 & 28 & 11 \\
\hline \# Obs. & 551 & 281,520 & 805 & 264,922 & 864 & 266,259 \\
\hline
\end{tabular}

Notes: Descriptive statistics for the working-age population (age 18-64). Arrival cohort 2001-2003: EU-8 immigrants in the 2004 microcensus who arrived between 2001 and 2003. Statistics for the arrival cohorts 2005-2007 and 2008-2009 calculated based on the 2008 and 2009 microcensus, respectively. Average wages: monthly nominal net income in Euro for workers with a positive income. Type of employment (permanent/temporary/self-employed) conditional on employment status.

Source: Own calculations from the German microcensus. 
Table 2 - Schooling and wage gap between EU8-Immigrants and Germans

\begin{tabular}{|c|c|c|c|c|c|c|}
\hline \multicolumn{7}{|c|}{ A: dependent variable: years of schooling } \\
\hline & \multicolumn{3}{|c|}{ Without sector FE } & \multicolumn{3}{|c|}{ With sector FE } \\
\hline & (1) & (2) & (3) & (1) & (2) & (3) \\
\hline & 2004 & 2008 & 2009 & 2004 & 2008 & 2009 \\
\hline Cohort & 0.184 & 0.038 & 0.007 & 0.409 & 0.257 & 0.259 \\
\hline $2001 / 03$ & $(0.113)$ & $(0.073)$ & $(0.075)$ & $(0.109)^{* * *}$ & $(0.071)^{* * *}$ & $(0.072)^{* * *}$ \\
\hline Cohort & & 0.808 & 0.991 & & 0.929 & 1.069 \\
\hline 2005/07 & & $(0.095)^{* * *}$ & $(0.094)^{* * *}$ & & $(0.088)^{* * *}$ & $(0.087)^{* * *}$ \\
\hline Cohort & & & 1.143 & & & 1.294 \\
\hline 2008/09 & & & $(0.136)^{* * *}$ & & & $(0.121)^{* * *}$ \\
\hline \multicolumn{7}{|c|}{ B: dependent variable: log monthly wage } \\
\hline & \multicolumn{3}{|c|}{ Education FE } & \multicolumn{3}{|c|}{ Education and sector $\mathrm{FE}$} \\
\hline & 2004 & 2008 & 2009 & 2004 & 2008 & 2009 \\
\hline Cohort & -0.410 & -0.248 & -0.236 & -0.244 & -0.163 & -0.149 \\
\hline $2001 / 03$ & $(0.036)^{* * *}$ & $(0.021)^{* * *}$ & $(0.021)^{* * *}$ & $(0.031)^{* * *}$ & $(0.020)^{* * *}$ & $(0.019)^{* * *}$ \\
\hline Cohort & & -0.189 & -0.135 & & -0.095 & -0.048 \\
\hline $2005 / 07$ & & $(0.029)^{* * *}$ & $(0.027)^{* * *}$ & & $(0.027)^{* * *}$ & $(0.025)^{* *}$ \\
\hline Cohort & & & -0.186 & & & -0.111 \\
\hline $2008 / 09$ & & & $(0.042)^{* * *}$ & & & $(0.038)^{* * *}$ \\
\hline
\end{tabular}

Note: The coefficients describe the estimated difference in schooling and income between different arrival cohorts of EU-8 migrants and Germans. Germans as the reference category is omitted from the regressions. 3 different census rounds $(2004,2008,2009)$ are used for the estimations. In all regressions we control for age, age squared, and gender. In columns 4-6 of panel A we include fixed effects for 6 sectors. All regressions in panel B additionally control for education. In columns 4-6 of panel B we include education fixed effects, sector fixed effects, and an interaction of education and sector dummies, so as to compare immigrants and natives with the same education and who are working in the same sector. For the sample sizes, see table 1. Robust standard errors in parentheses. ${ }^{*}(p<0.05),{ }^{* *}(p<0.01),{ }^{* * *}(p<0.001)$. 


\section{Endnotes}

\footnotetext{
${ }^{i}$ Rinne and Zimmermann (2012) have recently documented the causes for this surprising development.

ii EU8: Czech Republic, Estonia, Hungary, Latvia, Lithuania, Poland, Slovakia, Slovenia. EU2: Romania, Bulgaria.

iii See Christen (2004) for details on the legal framework.

${ }^{\text {iv }}$ The PIIGS are Portugal, Ireland, Italy, Greece, and Spain.

${ }^{v}$ Note that the large share of women in the stock data is at odds with the aggregate inflow data from the foreigners register, which reports an average ratio of men to women of 2:1. A reason for this discrepancy could be that men are predominantly short-term workers, while women potentially stay longer and are therefore more likely to be included in the census.
}

${ }^{\text {vi }}$ To do so, we include education dummies, sector dummies, and an interaction of education and sector dummies.

vii The earnings gap is conditional on working. Earnings are the monthly net income. As this is a categorical variable in the microcensus, we use the midpoints for each category, and multiply the threshold for the highest category with 1.5.

\footnotetext{
viii See Dustmann et al. (2010) for the characteristics of EU8 immigrants in the UK.

${ }^{\text {ix }}$ See Kahanec \& Zimmermann (2009) for a general analysis of this point.

${ }^{x}$ See Constant, Nottmeyer \& Zimmermann (2013) for a review of the available data and empirical evidence.
} 